\title{
SIMULATION OF MASS TRANSFER FROM PEACHES DURING COOL STORE AND ITS EFFECT ON SOME QUALITY PROPERTIES
}

\author{
Keshek' M. H. ${ }^{(1)}$; Omar, M. N. ${ }^{(1)}$ and Elsisi, S. F. ${ }^{(1)}$
}

\begin{abstract}
Peach is a popular product worldwide with its great coloration, high sweetness, alluring flavor and healthy benefit. Increasing of weight loss of fruit product is often observed in different points of a cold room leading to deterioration of fruit quality and safety. The aim of this study was simulation of moisture loss (mass transfer) from Swelling peaches during cold storage $\left(1^{\circ} \mathrm{C}\right.$ and $\left.\mathrm{RH} 95 \pm 5 \%\right)$ and determines its impact of quality properties (firmness and color). The result showed that, Good agreement between the simulated and experimental results was found for weight loss in cool room. The temperature difference between peaches tested and the cooling air after $24 \mathrm{~h}$ was in the range of $1.57{ }^{\circ} \mathrm{C}$ and half cooling time ranged from 1.25- 1.55 hour. The higher increasing of weight losses was $7.55 \%$ lead to decreasing of L value by $10.34 \%$ of flesh peaches while a value increased by $91.93 \%$ and $b$ value decreased by 11.65 of flesh peaches. the higher increasing of BI was 340.34 and 338.47 occurred after 25 days of cold storage and $7.55 \%$ of weight losses of flesh and skin color respectively. The total color change ( $\triangle E)$ during storage period for peaches was in the range from 1.9 to 9.94 and from 3.52 to 14.21 occurred after 25 days of cold storage and $7.55 \%$ of weight losses during cold storage for flesh and skin color respectively. The firmness decline rate was $15 \%$ after 5 days from cold storage period at $1.64 \%$ weight loss, which is less than the firmness decline rate of peaches $52.15 \%$ after 25 day from cold storage and $7.55 \%$ of water loss.
\end{abstract}

Keywords: Swelling Peach, Firmness, Half Cooling Time, Browning Index

(1) Agric. Eng. Dept., Fac. of Agric., Menoufia Univ., Egypt. 


\section{1- INTRODUCTION}

$\mathrm{P}$ each (Prunus persica) is one of the most important horticultural crops in the world because of its attractive taste and nutritive value

(Nunes, 2008). According to (FAO, 2016), the area cultivated with peach in Egypt is 48985 feddans and the total product of peach fruits is 266628 tons. Sweling peach is one of the late season cultivars that suffer from accelerated softened fruits, and therefore, the fruits exhibits short handling period, which limits its commercial potential. This concept obligates fruit producer to harvest fruits at early ripening stage. Accordingly, there is a great need to decrease fruit deterioration after harvest and to enhance fruit quality in order to prolong the handling season with acceptable yield (Ragab, 2002). The optimum peach storage temperature is $0{ }^{\circ} \mathrm{C}$ to $1.7{ }^{\circ} \mathrm{C}$. Preserving peach at this temperature will minimize deterioration resulting from internal browning and retard water loss and spoilage (Crisosto, et al., 2008). Cold storage is therefore commonly used to maximize their postharvest life, but due to the extreme perishability and susceptibility to chilling injury (CI) at prolonged exposure to temperatures below $10{ }^{\circ} \mathrm{C}$, or more severe under $2.2-7.6{ }^{\circ} \mathrm{C}$, peach easily develops woolliness, reducing consumer acceptance and limiting the commercial life (Crisosto, et al., 1995). Water loss from a fruit or vegetable is driven by the gradient in incomplete pressure of water vapor between the boundary layer over the product surface and its immediate condition. While the product surface boundary layer is sometimes assumed to be saturated $\left(\mathrm{a}_{\mathrm{w}}=1.0\right)$, the partial pressure at the evaporating surface isn't equivalent to the vapor pressure at the product surface temperature if there are broken up substances present as these lower the water activity at the evaporating surface (Ayman, et al., 2017). A steady state, mathematical model for showing the water loss of fruits and vegetables with shapes of spheres, cylinders and slabs. This model considered the internal heat of respiration, the convective and radiative heat transfer at the surface, surface cooling due to evaporation, and the effects of decreased water activity. Validation against experimental data was not presented (Elsisi, et al., 2017). A simplified model for 2-phase momentum, heat and mass transfer in an empty as well as loaded cold storage with horticultural product was established to simulated airflow 
around bins, air and product temperature as well as product water loss. The model equations were solved and validated by means of empirical data from a pilot cold room. An error of about $20 \%$ for velocity magnitude prediction for both the empty and loaded cool store was achieved. The model was capable of simulating the cooling rate of the air as well as the product (Nahor, et al., 2005). Each the heat and mass transfers are influenced by flow characteristics (such as cooling air temperature and velocity), air properties (viscosity, density, conductivity and specific heat), product properties, shape, dimension and arrangement of the load (Mirade and Daudin, 2006). Lurie, et al. (1986) observed that firmness decreased and water-soluble pectins increased with increasing water loss and that firmness remained high and water-soluble pectin concentration low if water loss was minimized. Components of fruits and vegetables that may differentiate their impact on weight change include fiber content, glycemic load (GL), and biologically active constituents like polyphenols and sugars. Higher fiber intake increases satiety, which in turn may reduce total energy intake and prevent weight gain (Mozaffarian. et al., 2011). Akdemir and Balb (2018) studied effect of cold-storage sensitive peaches cv. Glohaven in two different cooling systems and determine the quality parameter changes that occur during storage and resulted that variations in $\mathrm{L}$, $\mathrm{a}$ and $\mathrm{b}$ values indicated that as maturity increased the peach fruits exhibited a more intense and less bright reddish yellow colour. However, no significant effects by the storage and level differences were observed on brightness. There was an increase in 'a' values compared to the initial value (10.4) and it is possible that the red colour on the fruit skin became more visible. $b$ values showed fluctuation. After 7 days of cold storage, lemon and pepino was lower percentages of firmness loss $(26-40 \%)$ than stone fruits $55 \%$ (apricot, peaches, nectarine and plum), with $70-90 \%$ of loss in fruit firmness (Valero and Serrano, 2010). Refrigerated peaches decrease in flesh firmness, weight, acidity, and L component of the peel color, whereas SS and hue of the peel color do not show significant changes (Kader, 1999). The responses of Florida gold peach variety fruits to 2 and 4 weeks preservation at 2 and $5^{\circ} \mathrm{C}$ and $85 \% \mathrm{RH}$ were evaluated. According to the results of the research, this variety was found to be very 
susceptible to weight loss after storage for 4 weeks at $5^{\circ} \mathrm{C}$, indicating a decrease in firmness and acid content, an increase in total soluble solid and colour (VILLANUEVA, et al., 2000).

\section{MATERIALS and METHODS}

Fruit harvest and storage conditions Peach fruits (Prunus persica 'sweling') were harvested at commercial maturity from private farm in Al-Sadat-Menofia, Egypt, and immediately imparted to the laboratory where sorted for uniformity of size and lack of defects. Peaches were packed in carton boxes with the fruits touching $(40 \times 30 \times 12 \mathrm{~cm})$.

\subsection{Description of the cold room}

The cold room was $1.2 \mathrm{~m}$ long, $0.7 \mathrm{~m}$ wide and $1.2 \mathrm{~m}$ high (a total volume of $1.008 \mathrm{~m}^{3}$ ). Inside the cold room, 2 pallets (packages carton) 40 $\mathrm{cm}$ long, $30 \mathrm{~cm}$ wide and $75 \mathrm{~cm}$ high were placed. Each package has a vent hole ratio of $36 \%$. The cold room is located at the Agricultural Engineering department laboratory in Faculty of Agriculture, Menofia University. Cooling room is presented in Figure 1.
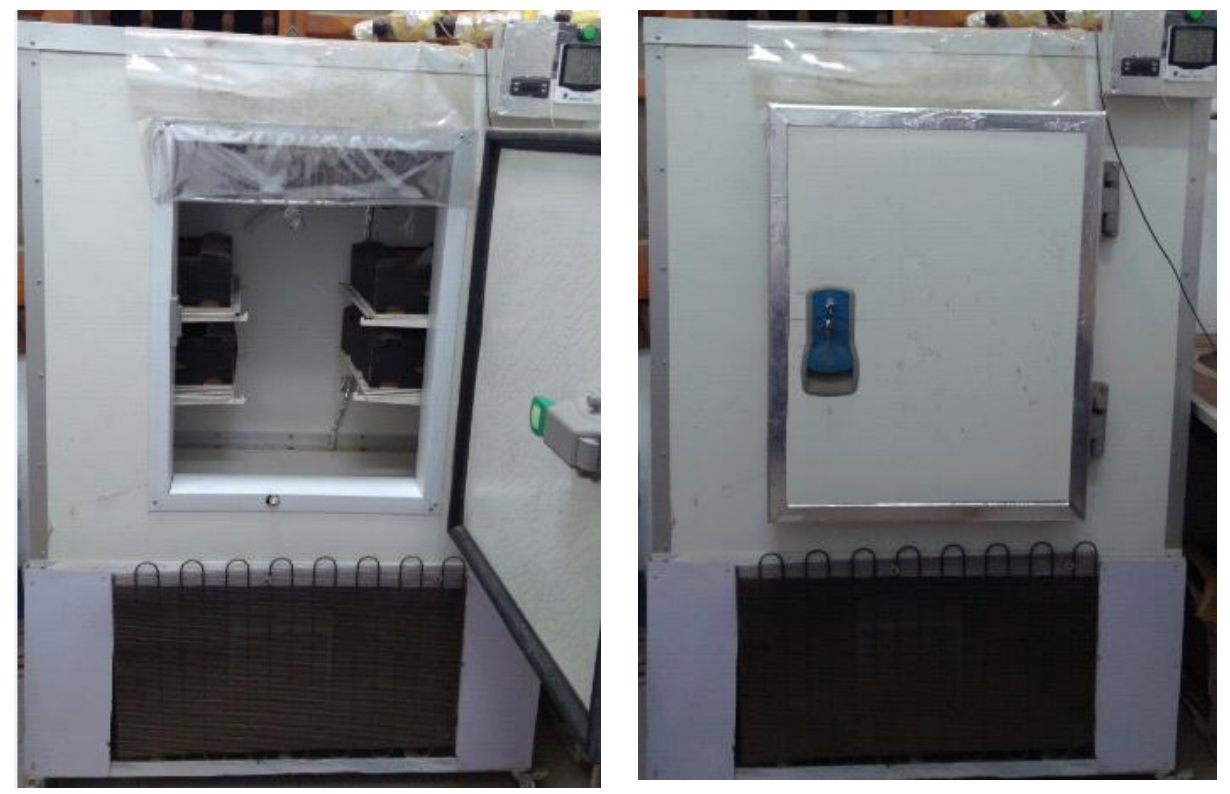

Figure 1. Photographic of peaches inside cold room

The geometrical parameters of the computational domain are reported in Table (3.1). 
PROCESS ENGINEERING

Table (3.1) Geometrical parameters of the cold room, pallet and package.

\begin{tabular}{lcc} 
& Number & Dimensions $($ length $\times$ width $\times$ height, in $\mathbf{m})$ \\
\cline { 2 - 3 } Cold room & 1 & $1.2 \times 1.2 \times 0.7$ \\
Pallet & 2 & $0.4 \times 0.3 \times 0.75$ \\
Package & 4/ pallet & $0.4 \times 0.3 \times 0.12$
\end{tabular}

\subsection{Model of mass transfer (Weight loss)}

The water loss of food products is driven by the gradient in water vapour density between the peaches skin and the surrounding air. A simple model was given by A simple model was proposed by Gwanpua, et al. (2012) in equation (3.1):

$$
\frac{\mathrm{dm}}{\mathrm{dt}}=\mathrm{K}_{\mathrm{ta}} \mathrm{A}_{\mathrm{s}}\left(\rho_{\mathrm{w}}-\rho_{\mathrm{w}, \infty}\right)
$$

Where $m$ is the weight loss, $\mathrm{Kg}_{\text {water }} ; \rho_{w}$ is the vapour density of the peaches surface, $\mathrm{kg}_{\text {water }} \mathrm{m}^{-3} ; \rho_{w, \infty}$ is the vapour density of the surrounding air, $\mathrm{kg}_{\mathrm{water}} \mathrm{m}^{-3} ; \mathrm{k}_{\mathrm{ta}}$ is the moisture transfer coefficient of the peaches skin, $\mathrm{m} \mathrm{s}^{-1} ; \mathrm{t}$ is the time, $\mathrm{s}$.

The mass transfer coefficient $\mathrm{k}_{\mathrm{ta}}$ is then calculated from $\mathrm{h}_{\mathrm{c}}$, was obtained from Gwanpua, et al. (2012) in equation (3.2).

$$
\mathrm{K}_{\mathrm{ta}}=\frac{\mathrm{h}_{\mathrm{c}}}{\rho_{R} \mathrm{C}_{\mathrm{pa}}(\mathrm{Le})^{2 / 3}}
$$

Where the Lewis number Le is calculated from equation 3.3:

$$
\text { Le }=\frac{\mathrm{K}_{\mathrm{a}}}{\rho_{R} \mathrm{C}_{\mathrm{pa}} \mathrm{D}_{\mathrm{air}}}
$$

Where $\mathrm{h}_{\mathrm{c}}$ is the convection heat transfer coefficient, $\mathrm{W} \mathrm{m}^{-2} \mathrm{~K}^{-1} ; \rho_{R}$ is the density of air inside of cold room, $\mathrm{kg} \mathrm{m}^{-3} ; \mathrm{C}_{\mathrm{p}}$ is the specific heat of air cooling, $\mathrm{J} \mathrm{kg}^{-1}{ }^{0} \mathrm{C}^{-1} ; \mathrm{K}_{\mathrm{a}}$ is the thermal conductivity of air, $\mathrm{W} \mathrm{m} \mathrm{m}^{-1} \mathrm{~K}^{-1}$; $\mathrm{D}_{\text {air }}$ is the diffusivity of water in air, $\mathrm{m}^{2} \mathrm{~s}^{-1}$.

$\rho_{\mathrm{w}}$ is related to the saturated vapour pressure $\mathrm{P}_{\mathrm{sat}}(\mathrm{Pa})$ at peach surface temperature $\mathrm{T}_{\mathrm{s}}(\mathrm{K})$ as equation (3.4) and equation (3.5) (Taha, 2003):

$$
\rho_{\mathrm{w}}=\frac{\mathrm{M}_{\mathrm{H} 2 \mathrm{O}} \mathrm{P}_{\mathrm{sat}, \mathrm{surf}}\left(\mathrm{T}_{\mathrm{s}}\right) \mathrm{a}_{\mathrm{w}}}{\text { R.T } \mathrm{T}_{\mathrm{s}}}
$$


PROCESS ENGINEERING

$$
\mathrm{P}_{\text {sat,surf }}=0.61078 \exp \left[\frac{17.269388 \mathrm{Ts}}{\mathrm{T}_{\mathrm{s}}+237.3}\right] \quad 3.5
$$

Where $\mathrm{P}_{\text {sat,surf }}$ is the saturated vapour pressure at peach surface temperature, $\mathrm{Pa} ; \mathrm{M}_{\mathrm{H} 2 \mathrm{O}}$ is the molar mass of water, $\mathrm{kg} \mathrm{mol}^{-1}(=0.018)$; $\mathrm{R}$ is the universal gas constant, $8.314 \mathrm{~J} \mathrm{~mol}^{-1} \mathrm{~K}^{-1}$; $\mathrm{a}_{\mathrm{w}}$ is the water activity of the peach; $\mathrm{T}_{\mathrm{s}}$ is the peach surface temperature ${ }^{0} \mathrm{C}$.

The expression of $\rho_{\mathrm{w}, \infty}$ is the same as for $\rho_{\omega}$ by replacing the water activity by the relative humidity $(\mathrm{RH})$ and the saturated vapour pressure $\mathrm{P}_{\text {sat }}(\mathrm{Pa})$ at cooling air temperature $\mathrm{T}_{\mathrm{a}}(\mathrm{K})$ as equations (3.6), (3.7) and (3.8). The thermophysical properties of air are listed in Table 3.2.

$$
\begin{array}{ll}
\rho_{\mathrm{w}, \infty}=\frac{\mathrm{M}_{\mathrm{H} 2 \mathrm{O}} \mathrm{P}_{\mathrm{w}, \text { air }}}{\mathrm{R} \cdot \mathrm{T}_{\mathrm{a}}} & 3.6 \\
\rho_{\mathrm{w}, \text { air }}=\mathrm{P}_{\text {sat,air }}\left(\mathrm{T}_{\mathrm{a}}\right) \frac{\mathrm{RH}}{100} & 3.7 \\
\mathrm{P}_{\text {sat,air }}=0.61078 \exp \left[\frac{17.269388 \mathrm{Ta}}{\mathrm{T}_{\mathrm{a}}+237.3}\right] & 3.8
\end{array}
$$

Where $\mathrm{P}_{\text {sat,surf }}$ is the saturated vapour pressure at peaches surface temperature, $\mathrm{Pa} ; \mathrm{P}_{\text {sat,air }}$ is the saturated vapour pressure at air cooling temperature, $\mathrm{Pa} ; \mathrm{RH}$ is the relative humidity $\%$. The thermophysical properties of air are listed in Table 3.1.

Table 3.1. Air properties at $1^{\circ} \mathrm{C}$ (Veraverbeke, et al., 2003)

\begin{tabular}{lll}
\hline Density $\left({ }_{\mathrm{r}}\right)$ & 1.29 & $\mathrm{~kg} \mathrm{~m}^{-3}$ \\
\hline Thermal conductivity $\left(\mathrm{K}_{\mathrm{a}}\right)$ & 0.025 & $\mathrm{~W} \mathrm{~m}^{-1} \mathrm{C}^{-1}$ \\
\hline Specific heat of cooling air $\left(\mathrm{C}_{\mathrm{pa}}\right)$ & 1004 & $\mathrm{~J} \mathrm{~kg}^{-1} \mathrm{C}^{-1}$ \\
\hline Diffusivity of water in air $\left(\mathrm{D}_{\text {air }}\right)$ & $2.1 * 10^{-5}$ & $\mathrm{~m}^{-2} \mathrm{~s}^{-1}$ \\
\hline
\end{tabular}

\subsubsection{Convection heat transfer coefficient}

The convection heat transfer coefficient $h_{c}$ can be estimated by using the Nusselt-Reynolds-Prandtl correlations (Incropera and DeWitt, 1990). The Nusselt number $\mathrm{Nu}$ is defined as equation 3.9:

$$
\mathrm{Nu}=\frac{\mathrm{h}_{\mathrm{c}} \mathrm{d}}{\mathrm{K}_{\mathrm{a}}}
$$

Because the convective mass transfer processes are governed by similar mechanisms, Nusselt-Reynolds-Prandtl correlations can be calculated by following Equations (3.10), (3.11), (3.12), (3.13) and (3.14). 


$$
\begin{aligned}
& \mathrm{Nu}=2+0.6 \mathrm{Re}^{0.5} \operatorname{Pr}^{0.33} \quad 3.10 \\
& \operatorname{Pr}=\frac{U}{\alpha} \quad 3.11 \\
& v=\frac{\mu}{\rho_{R}} \quad 3.12 \\
& \alpha=\frac{\mathrm{K}_{\mathrm{p}}}{\rho_{\mathrm{p}} \mathrm{C}_{\mathrm{p}}} \\
& \operatorname{Re}=\frac{\mathrm{u}_{\infty} \mathrm{d}}{v}
\end{aligned}
$$

For the temperature range of $-40^{\circ} \mathrm{C}$ to $120^{\circ} \mathrm{C}\left(-40^{\circ} \mathrm{F}\right.$ to $\left.250^{\circ} \mathrm{F}\right)$, the viscosity of moist air varies little from that of dry air (ASHRAE, 1993). Therefore, the dynamic viscosity of moist air is approximated by that of dry air at the same temperature by using the following relationship, which was obtained via a least-squares fit of dry air data reported by ASHRAE (1993):

$$
\mu=17.19+0.0429 \mathrm{~T}_{\mathrm{a}} \quad 3.15
$$

Where $\mathrm{Nu}$ is the Nusselt number; Re is the Reynolds number; $\mathrm{Pr}$ is the Prandtl number; is the $h_{c}$ convection heat transfer coefficient, $w / m^{2}$; $d$ is the diameter of peaches, $\mathrm{m} ; u_{\infty}$ is the air velocity, $\mathrm{m} \mathrm{s}^{-1}$; $v$ is the kinematic viscosity of air, $\mathrm{m}^{2} \mathrm{~s}^{-1} ; \mu$ is the dynamic viscosity of air, $10^{-6} \mathrm{Ns}$ $\mathrm{m}^{-2} ; \mathrm{k}_{\mathrm{a}}$ is the thermal conductivity of air $\mathrm{W} \mathrm{m} \mathrm{m}^{-1} \mathrm{~K}^{-1} ; \mathrm{K}_{\mathrm{p}}$ is the thermal conductivity of peaches, $\mathrm{W} \mathrm{m}{ }^{-1} \mathrm{~K}^{-1} ; \mathrm{C}_{\mathrm{p}}$ Specific heat of peaches, $\mathrm{J} \mathrm{kg}^{-1}{ }^{0} \mathrm{C}^{-}$ ${ }^{1} ; \alpha$ Thermal diffusivity of peaches, $\mathrm{m}^{2} \mathrm{~s}^{-1}$ and $\rho_{R}$ Density of air inside of the refrigerator, $\mathrm{kg} \mathrm{m}^{-3}$

The thermo-physical properties of peaches (Swelling variety) are presented in Table 3.2.

Table (3.2). Thermo-physical properties of peaches (Swelling variety) (Bryan et al., 2011).

Thermal conductivity of peach, $\mathrm{W} \mathrm{m}^{-1} \mathrm{~K}^{-1}\left(\mathrm{~K}_{\mathrm{p}}\right) \quad 0.550$

Specific heat of peach, $\mathrm{J} \mathrm{kg}^{-1} \mathrm{~K}^{-1}\left(\mathrm{C}_{\mathrm{p}}\right) \quad 3910$

Density of the peach, $\mathrm{kg} \mathrm{m}^{-3}\left(\rho_{\mathrm{p}}\right) \quad 857$ 


\subsection{Cooling time and cooling rate}

The cooling ratio (sin. temperature ratio, $\mathrm{Y}$ ) is the unaccomplished temperature change as a percentage of the total cooling possible in the system. This ratio is calculated by equation 3.16, where, $\mathrm{T}$ is the flesh temperature $\left({ }^{\circ} \mathrm{C}\right)$ at the time $\mathrm{t}(\mathrm{h}), \mathrm{T}_{\text {air }}$ is temperature in the cooling fluid $\left({ }^{\circ} \mathrm{C}\right)$, and $\mathrm{T}_{\mathrm{i}}$ is the initial temperature of the flesh $\left({ }^{\circ} \mathrm{C}\right)$.

$$
Y=\frac{\mathrm{T}-\mathrm{T}_{i}}{\mathrm{~T}_{\mathrm{i}}-\mathrm{T}_{\text {air }}} \ldots \ldots \ldots \ldots . . . . .3 .16
$$

Cooling time also may be simulated using the cooling coefficient. The cooling coefficient indicates the change in the fractional unaccomplished temperature difference between the product and its surrounding climate per unit change in cooling time (ASHRAE, 2006). Under the nonNewtonian heat transfer conditions that often occur in postharvest situations, $\mathrm{C}$ is calculated using equation 3.17, where the subscripts for $\mathrm{Y}$ and $\mathrm{t}$ indicate sampling times.

$$
C=\frac{\ln Y_{1}-\ln Y_{2}}{t_{1}-t_{2}}
$$

The half-cooling time $\left(\mathrm{t}_{1 / 2}\right)$ is time required to remove one-half and reduce the temperature difference between the product and the cooling air by one-half and is calculated from the cooling coefficient (Equation 3.18). $\mathrm{d}$

$$
t_{1 / 2}=\frac{\ln \left(\frac{1}{2}\right)}{\mathrm{C}}
$$

The instantaneous cooling rate $\left(R\right.$, expressed in $\left.{ }^{\circ} \mathrm{C} \mathrm{h}^{-1}\right)$ is calculated with Equation 3.19.

$$
R=C\left(\mathrm{~T}-\mathrm{T}_{0}\right)
$$

\subsection{Measurements}

Cooling air temperatures and air velocity were measured in upper (at 75 $\mathrm{cm}$ of pallets) and down (at $15 \mathrm{~cm}$ of pallets) of cold store at $1{ }^{\circ} \mathrm{C}$ (Thermostat set) relative humidity $95 \% \pm 5 \%$

\section{Temperature measurements}

Air temperature inside cold storage and surface temperature of peaches and ambient temperature were measured using T-type thermocouples (1 mm diameter, precision $\pm 0.2{ }^{0} \mathrm{C}$ ) in cold room. The temperatures were determined at two levels located at different height: upper $(75 \mathrm{~cm})$, down $(15 \mathrm{~cm})$ of pallets at storage temperature $1^{0} \mathrm{C}$. Four thermocouples of 
peaches surface and four air temperatures around peaches. All data collected by CR23X data logger.

\section{Air velocity measurements}

Velocity measurements were performed to describe the airflow in the entire cold room in terms of magnitude. A hot wire anemometer (TES 1341) was used because of its good balance between cost, accuracy and convenience (Melikov, et al., 2007). Measurements were carried in 16 points at two different heights $(75 \mathrm{~cm}$ and $15 \mathrm{~cm})$ in the loaded cold room.

\section{Wight losses}

20 peaches were selected from cold storage during storage period to compare the peaches weight loss at upper and down positions in the cold room and in subsequent work, to validate a model of quality evolution. These were determined by using a digital weighing balance. The GP4102 digital balance used in this work was used for determining the weight samples of peach at each storage time.

\subsection{Flow diagram of mass transfer model}

Figures 2 show flow chart of mass transfer model. The following result of model was weight loss of peaches $(\mathrm{g})$.

\subsection{Quality properties of Peaches}

Weight losses, firmness and color of peaches were measured at two different positions, upper and down position in cold room, using three samples of package. Samples of 20 peaches were first weighed to measure weight losses before cold storage and it measured each two days during storage period for the same samples.

\section{Firmness}

Fruit firmness was measured by FHT-1122 hardness tester and related with quill diameter of $3.5 \mathrm{~mm}$ were pressed peach until penetration and then take the reading device. This test measured peach firmness based on the resistance of the flesh of a peach to deformation by the plate (Kader, 2002). Three replicates of 3 peach of package at different position were used for storage period. Firmness was measured for full fruit in to position as showed in Figure 3. 


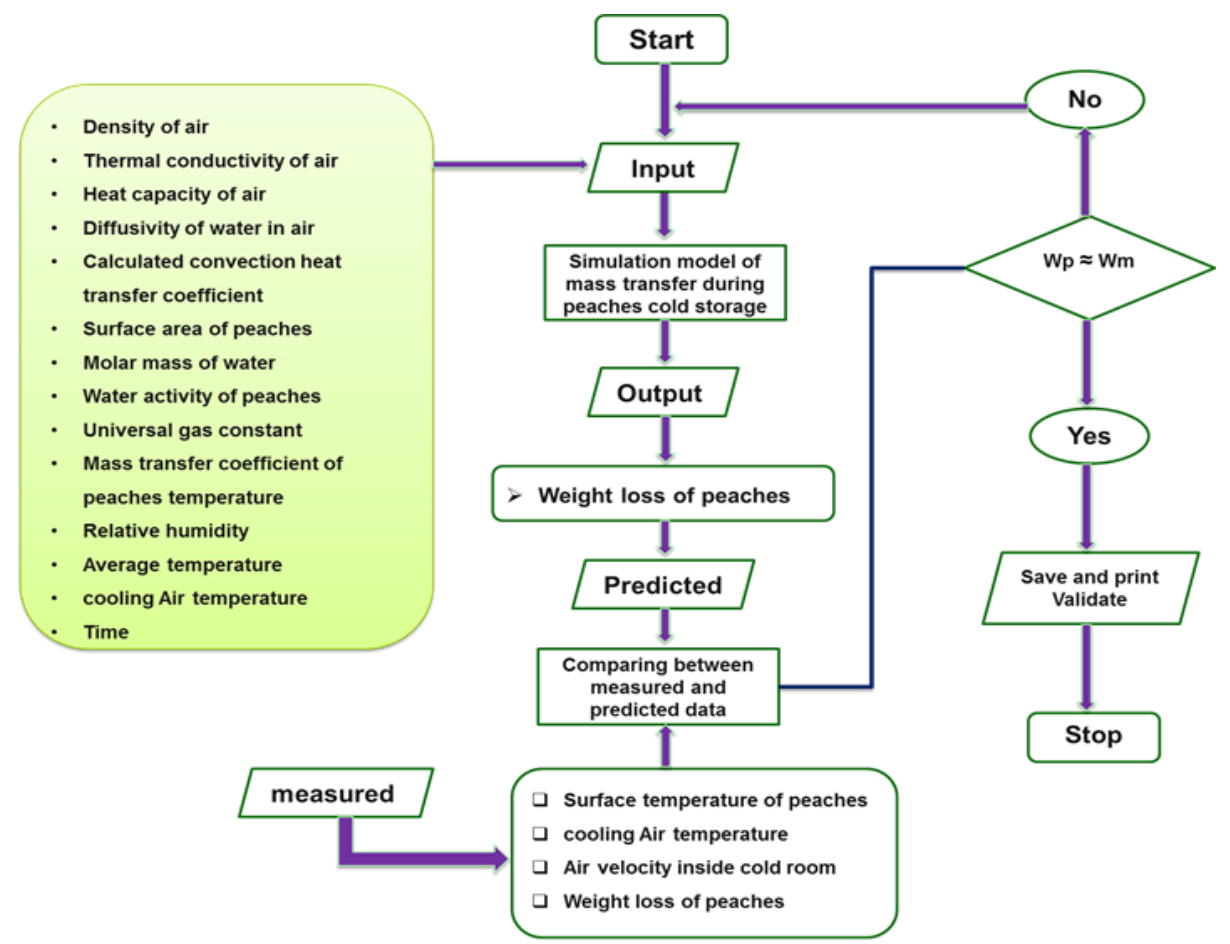

Figure 2. Schematic diagram of basic simulation approach and illustration

\section{Color determination}

\section{of the mass transfer model input}

Peaches colour was determined with a WR-10 Colorimeter Figure 4. Chroma values were the means of three determinations for each fruit along the equatorial axis. The lightness $\mathrm{L}$, $\mathrm{a}$ and $\mathrm{b}$ values. $\mathrm{L}$, refers to lightness of the color of the sample fruit and ranges from black $=0$ to white $=100$. A negative value of a indicates a green color where the positive value indicates red-purple color. A positive value of $b$ indicates a yellow color and the negative value a blue color. The $\mathrm{L}$ value is a useful indicator of darkening during storage, either resulting from oxidative browning reactions or from increasing pigment concentrations. The enzymatic browning at the cut surfaces of peaches could be monitored by measuring changes in reflectance $\mathrm{L}$, $\mathrm{a}$ and $\mathrm{b}$ values seemed to be unrelated to the extent of browning. The average color parameters of flesh and skin fresh peaches were used as a reference $(\mathrm{L}=59.81$ and 52.56, $\mathrm{a}=$ 5.63 and $12.87, b=49.84$ and 39.2 respectively). The change in the surface color of the sample, which was referred to as the total color 
difference. Then, the total color difference $(\Delta \mathrm{E})$ and browning index $(\mathrm{Bi})$ were determined using the following equations (3.20), (3.21) and (3.22):

$$
\begin{aligned}
& \Delta \mathrm{E}=\sqrt{(\Delta \mathrm{L})^{2}+(\Delta \mathrm{a})^{2}+(\Delta \mathrm{b})^{2}} \\
& \mathrm{Bi}=\frac{[100(\mathrm{x}-0.31)]}{0.17} \\
& \mathrm{x}=\frac{(\mathrm{a}+1.75 \mathrm{~L})}{(5.645 \mathrm{~L}+\mathrm{a}-3.012 \mathrm{~b})}
\end{aligned}
$$

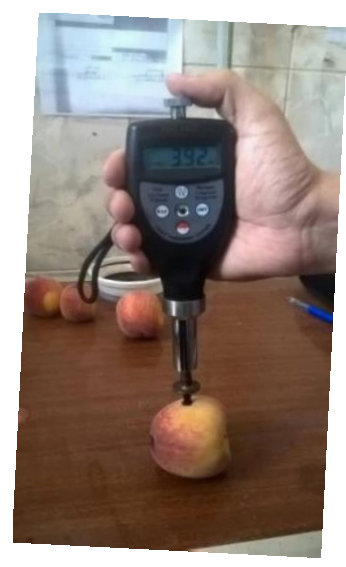

Figure 3. Fruit Hardness Tester, FHT-1122

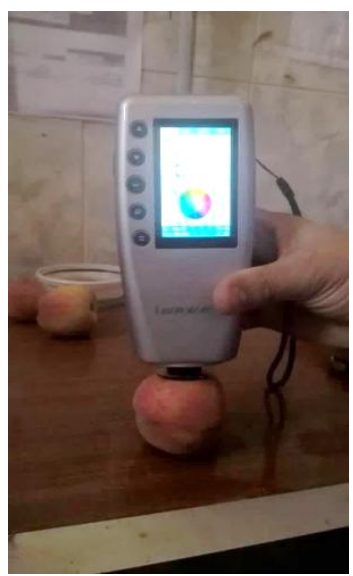

Figure 4. WR-10 Colorimeter

\section{RESULTS}

\subsection{Cooling rate of peaches cold storage.}

Mean initial temperature of peaches was $25 \pm 0.8^{\circ} \mathrm{C}$. Cooling time of peaches varied proportionally with temperatures dropping to $8.57^{\circ} \mathrm{C}$ $\left(\mathrm{TAT}_{1 / 2}\right)$ in time spans ranging from 1.25 hour to 1.55 hour as shown Figure 5. The period of storage will be longer depending on the final temperature intended for the product. Where final temperature of peaches ranged from $1.28^{\circ} \mathrm{C}$ to $1.57^{\circ} \mathrm{C}$ after cooling time from 3 hours to 4 hours. The temperature difference between peaches tested and the refrigeration air after $24 \mathrm{~h}$ was in the range of $1.57{ }^{\circ} \mathrm{C}$. A $0.3-0.5{ }^{\circ} \mathrm{C}$ difference between refrigerated peaches and air cooling. This difference was attributed to heat generation by respiration and to the slower heat transfer from inside the carton package to the outside cooling air. 


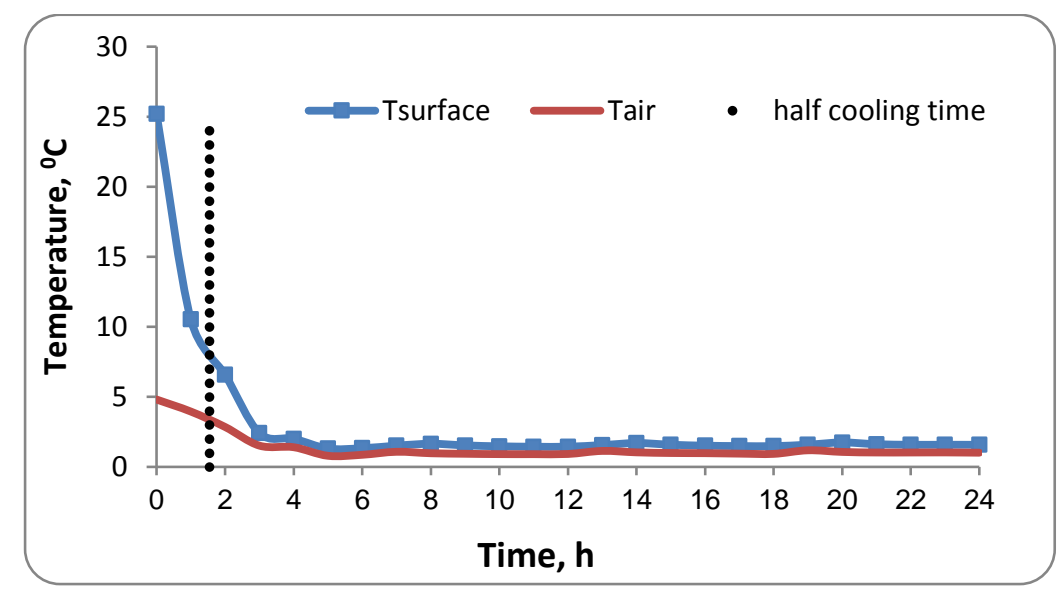

Figure 5. Cooling rates of peaches cold storage at $1^{\circ} \mathrm{C}$ and $\mathrm{RH} 95 \pm 5 \%$.

\subsection{Weight loss model of peaches during cold storage}

Solving the model resulted in a series of moisture profiles are possible from which the corresponding motion after difference time intervals was determined and converted to a percentage weight loss for a whole peaches by integration over the initial peaches weight. In general, the moisture loss has a quasi-linear relationship with time up to 25 day of storage. Then, the moisture loss rate reduces with storage period.

The weight loss $(\%)$ of peaches after 25 days was extrapolated based on the weight loss rate every 2 days until the first 15 day of storage period and each five days until the end of the cooling phase (25 days). The average of experimental weight loss after the end of cooling period (25days) was 7.19 and $7.66 \%$ at down and upper position of the pallet in cold room, respectively. While average of simulated weight loss after the end of cooling period was 7.22 and $7.81 \%$ at down and upper position of the pallets, respectively as shown Figure 6. Fruit weight loss during storage is influenced by the surrounding temperature, humidity, and airflow, also water losses decrease is likely because of two phenomena: the decrease in physiological action, as confirm by the decline in the respiration rate and the vapor pressure shortage between the product and the surrounding air as the pressure increase (Ayman, et al. 2017). 
The correlation coefficients between the measured and the predicted values of weight loss (\%) during the simulation periods for down and upper were 0.99 and 0.98 for upper and down positions, respectively as shown Figure 7 and Figure 8. these results of mass transfer model are agreement with the results of Laguerre, et al. (2015), Ayman, et al. (2017).

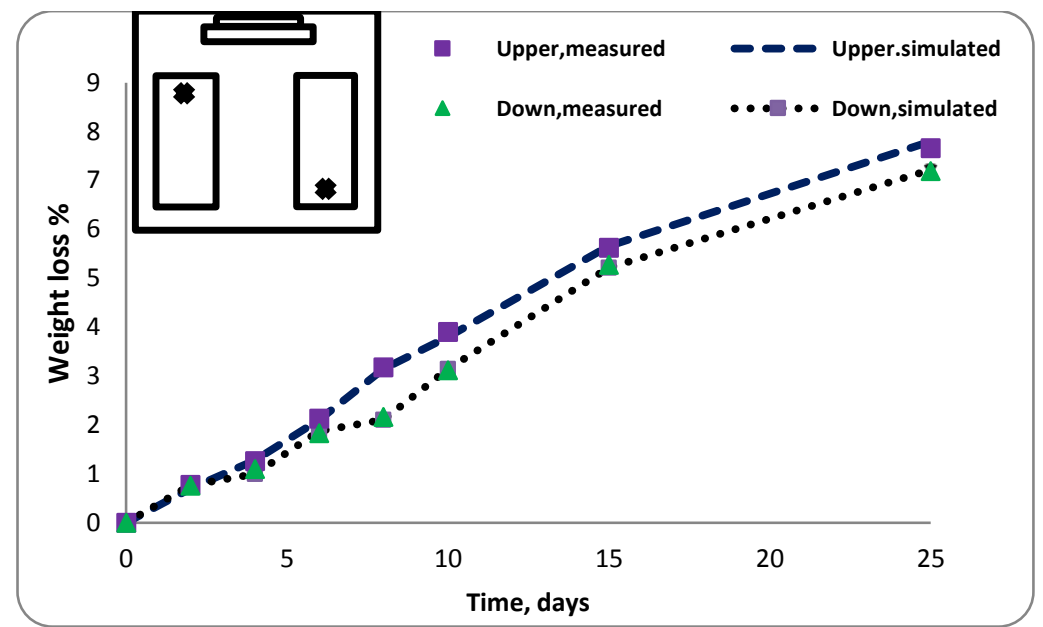

Figure 6. Measured and simulated weight losses of peaches at the upper and down position during 25 days of storage at $1^{\circ} \mathrm{C}$ and $\mathrm{RH} 95 \pm 5 \%$.

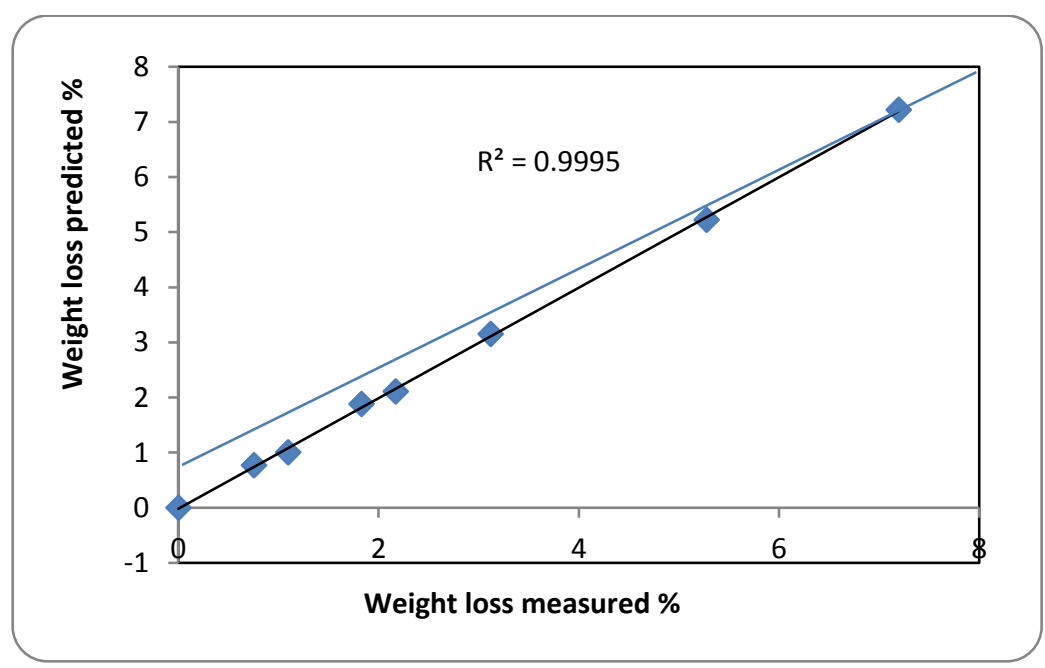

Figure 7. Comparison between measured and simulated values of weight losses of peaches at upper position $\left({ }^{0} \mathrm{C}, \mathrm{RH} 95 \pm 5 \%\right)$. 


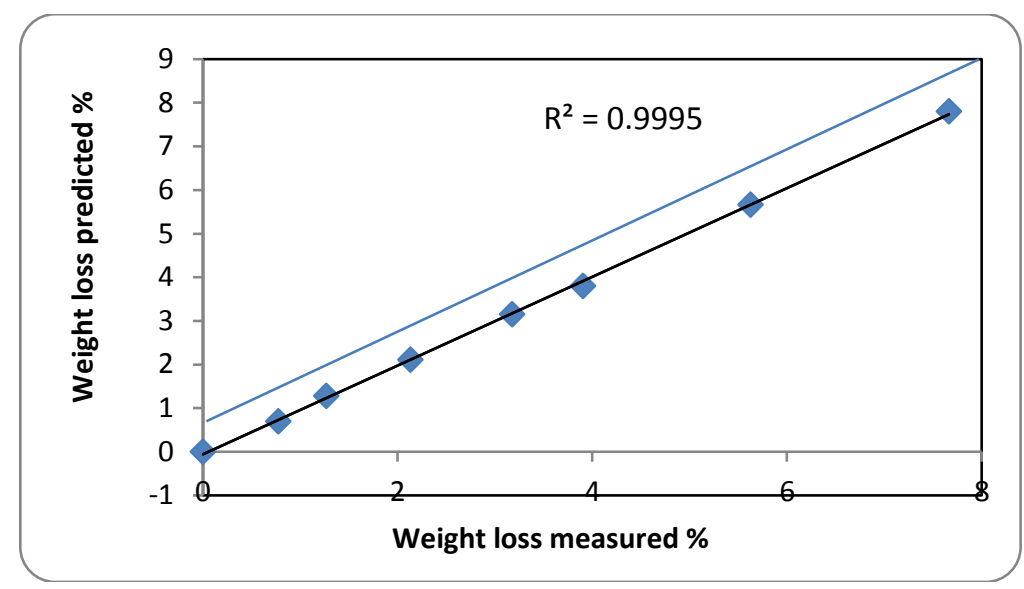

Figure 8. Comparison between measured and simulated values of weight losses of peaches at down position $\left({ }^{0} \mathrm{C}, \mathrm{RH} 95 \pm 5 \%\right)$.

\subsection{Quality properties of peaches during cold storage}

Weight loss is an important factor in estimating the deterioration of quality since produce that is liable to excessive weight loss shows poor appearance, soft texture and lower nutritional benefit. So the weight loss is an important factor effecting of some quality properties such as color and firmness therefore it shelf life.

\subsubsection{Effect of weight losses on peaches color parameters.}

The evaluation considered the appearance color, the lightness ( $\mathrm{L}$ value), green/red components (a value), blue/yellow components (b value), the total color difference $(\Delta \mathrm{E})$ and browning index $(\mathrm{BI})$.

Figure 9 show the effect of storage period on $\mathrm{L}$ value of flesh and skin color of peaches with weight losses during cold storage, from this figure we can obtained that the $\mathrm{L}$ value gradually decrease by increasing time of cold storage and increasing weight loss. The initial $\mathrm{L}$ values were 59.81 and 52.56 of flesh and skin color respectively and the higher decreasing of L values were 53.62 and 44.33 occurred after 25 days of cold storage and $7.55 \%$ of weight losses of flesh and skin color respectively, but at $1.62 \%$ weight losses the decreasing of $\mathrm{L}$ values was 57.98 and 50.42 occurred after 5 days of cold storage for flesh and skin color respectively. Variation in color parameters during storage duration may be to the burst of ethylene gas and increase respiration rate that signals genes to 
transform chloroplasts, chlorophyll is gradually replaced by the carotenoids.

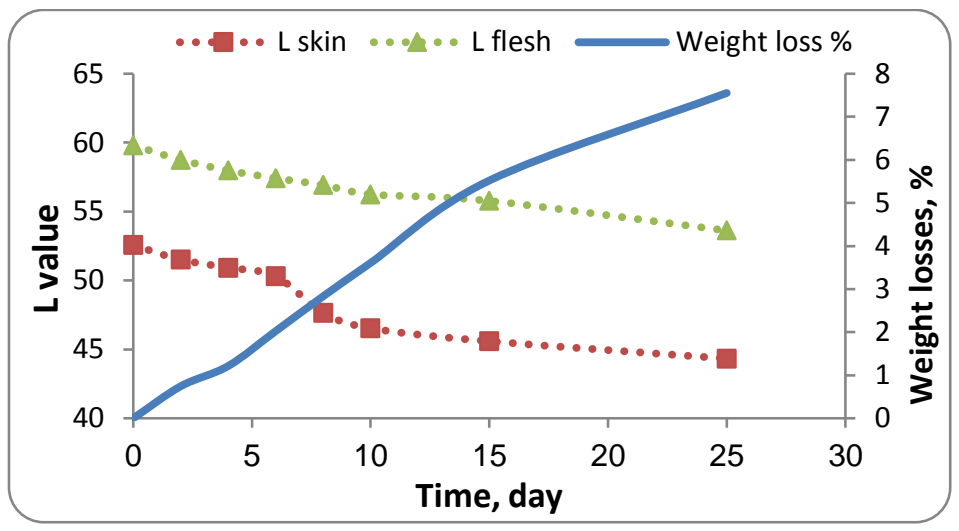

Figure 9: Effect of cold storage shelf life on $L$ value of peaches (skin and flesh) and weight losses.

Figure 10 show the effect of storage period on a value of flesh and skin color of peaches with weight losses during cold storage, from this figure we can obtained that the a value gradually increase by increasing time of cold storage and increasing weight loss. The initial a values was 5.63 and 12.87 of flesh and skin color respectively, and the larger increasing of a values was 10.8 and 22.87 occurred after 25 days of cold storage and $7.55 \%$ of weight losses of flesh and skin color respectively, but at $1.62 \%$ weight losses the increasing of a values was 6.85 and 16.65 occurred after 5 days of cold storage for flesh and skin color respectively. They accepted that changes were because of enzymatic browning caused by tissue harm with consequent improved contact among enzymes and substrates. The expansion in $\mathrm{a}^{*}$ estimation of peaches tissue demonstrates degradation of chlorophyll Paulina, et al. (2016).

Figure 11 show the effect of storage period on $b$ value of flesh and skin color of peaches with weight losses during cold storage, from this figure we can obtained that the $b$ value gradually decrease by increasing time of cold storage and increasing weight loss. The initial L values was 49.84 and 39.2 of flesh and skin color respectively and the higher decreasing of b values were 44.03 and 33.35 occurred after 25 days of cold storage and $7.55 \%$ of weight losses of flesh and skin color respectively, while after 5 
days of cold storage the decreasing of $b$ values was 48.32 and 37.92 occurred at $1.62 \%$ weight losses for flesh and skin color respectively.

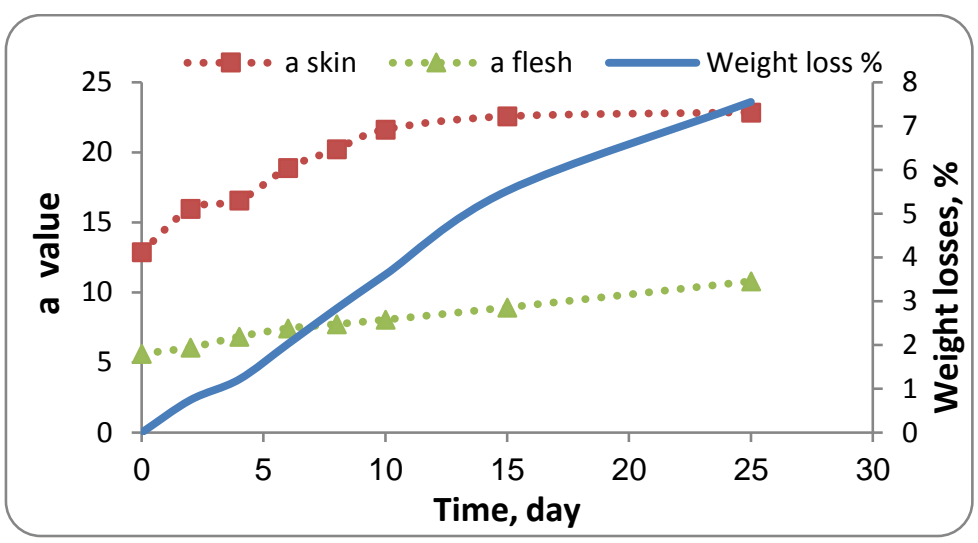

Figure 10: Effect of cold storage shelf life on a value of peaches (skin and flesh) and weight losses.

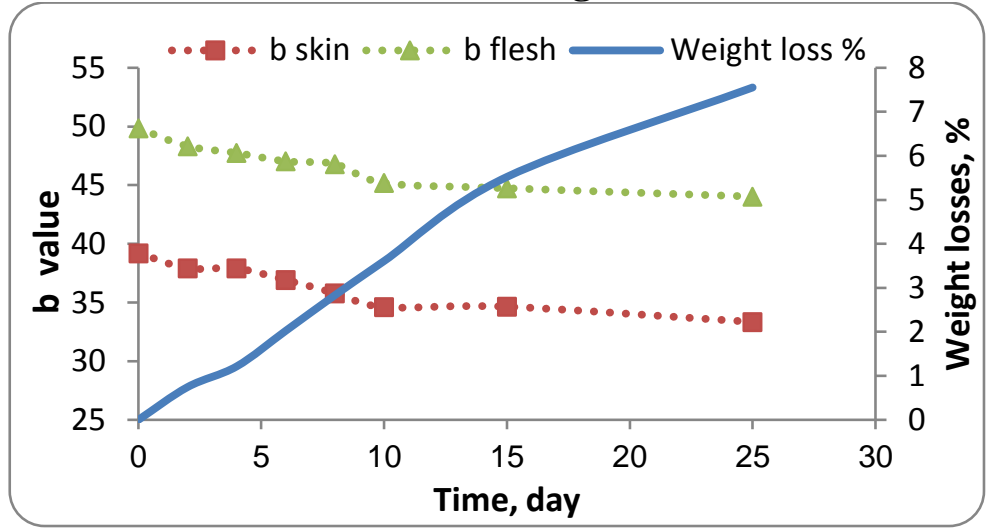

Figure 11: Effect of cold storage shelf life on $b$ value of peaches (skin and flesh) and weight losses.

Table (4.1) show the decline rate of $\mathrm{L}$ and $\mathrm{b}$ value and increasing rate of $\mathrm{a}$ value with increasing rate of peaches weight loss during shelf life cold storage. The results in this table refer to changing of weight loss percentage with time period accompanied by change of color parameter of peaches, where the largest increasing of weight losses was $7.55 \%$ lead to decreasing of $\mathrm{L}$ value by $10.34 \%$ of flesh peaches while a value increased by $91.93 \%$ and $b$ value decreased by 11.65 of flesh peaches. The ideal duration for cold storage of peaches from 11 to 14 day because weight losses was less than $5 \%$ and the change of color parameter in this 
period was not great compared to period from 15- 25 day at experimental cold storage conditions $\left(1^{0} \mathrm{C}, \mathrm{RH} 95 \pm 5 \%\right)$.

Table (4.1) effect of cold storage shelf life on decreasing of weight losses of peaches and its relation quality properties.

\begin{tabular}{|c|c|c|c|c|c|c|c|c|}
\hline \multirow{3}{*}{$\begin{array}{l}\text { Shelf life } \\
\text { of } \\
\text { peaches } \\
\text { cold } \\
\text { storage } \\
\text { (day) }\end{array}$} & \multirow{3}{*}{$\begin{array}{l}\text { Weight } \\
\text { loss (\%) }\end{array}$} & \multicolumn{6}{|c|}{ Color parameters } & \multirow{3}{*}{$\begin{array}{c}\begin{array}{c}\text { Decreasing } \\
\text { of }\end{array} \\
\text { Firmness } \\
\%\end{array}$} \\
\hline & & \multicolumn{2}{|c|}{$\begin{array}{c}\text { Decreasing of } \mathrm{L} \\
\%\end{array}$} & \multicolumn{2}{|c|}{$\begin{array}{c}\text { Increasing of a } \\
\%\end{array}$} & \multicolumn{2}{|c|}{$\begin{array}{c}\text { Decreasing of } \\
\text { b } \%\end{array}$} & \\
\hline & & skin & flesh & skin & flesh & skin & flesh & \\
\hline 5 & 1.62 & 3.11 & 3.06 & 28.79 & 21.73 & 3.30 & 4.20 & 15.55 \\
\hline 10 & 3.61 & 11.48 & 5.95 & 68.09 & 43.24 & 11.73 & 9.32 & 28.14 \\
\hline 15 & 5.52 & 13.27 & 7.23 & 75.35 & 58.73 & 11.64 & 10.23 & 45.03 \\
\hline 25 & 7.55 & 15.66 & 10.34 & 77.61 & 91.93 & 14.94 & 11.65 & 52.15 \\
\hline
\end{tabular}

Figure 12 show the influence of cold storage duration on browning index (BI). The browning index increased with increasing cold storage period and by increasing weight loss. The initial BI was 320.25 and 334.1 of flesh and skin color respectively and the higher increasing of BI was 340.34 and 338.47 occurred after 25 days of cold storage and $7.55 \%$ of weight losses of flesh and skin color respectively. The found results of PPO (Polyphenol oxidase) is the key enzyme related to browning in peaches fruits.

The total color change $(\Delta \mathrm{E})$ during the storage period for peaches was in the range from 1.9 to 9.94 and from 3.52 to 14.21 occurred after 25 days of cold storage and $7.55 \%$ of weight losses during cold storage for flesh and skin color respectively, as shown Figure 13. After 5 days of cold storage the $\Delta \mathrm{E}$ was 2.62 and 3.47 occurred at $1.62 \%$ weight losses for flesh and skin color respectively.

\subsubsection{Effect of weight losses on peaches firmness.}

The fruit firmness showed a decreasing trend as the storage period and increasing weight loss advanced figure (13). The moisture losses lead to reduction of peaches firmness. The highest peaches firmness $36.09 \mathrm{~N}$ was recorded in initial storage duration, after 10 day from duration cold store was $25.93 \mathrm{~N}$ where weight loss was $3.61 \%$ while the lowest peaches firmness $17.57 \mathrm{~N}$ was recorded after 25 day from cold storage and $7.55 \%$ of water loss. 


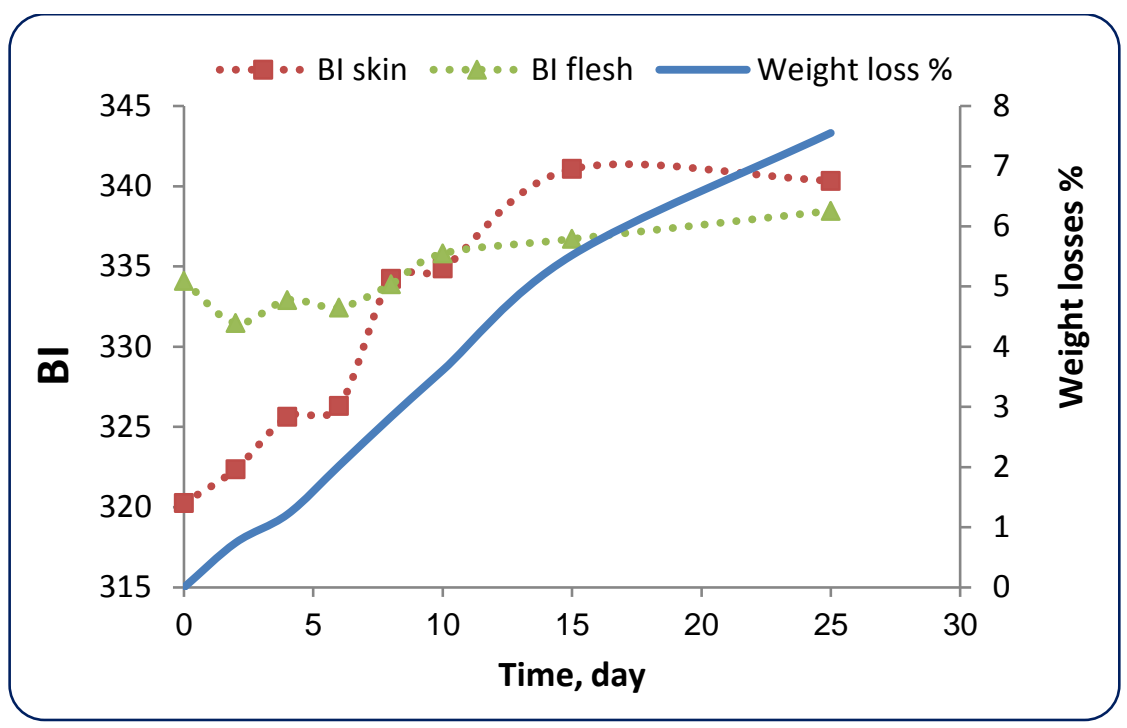

Figure 12: Effect of cold storage shelf life on browning index (BI) of peaches (skin and flesh) and weight losses.

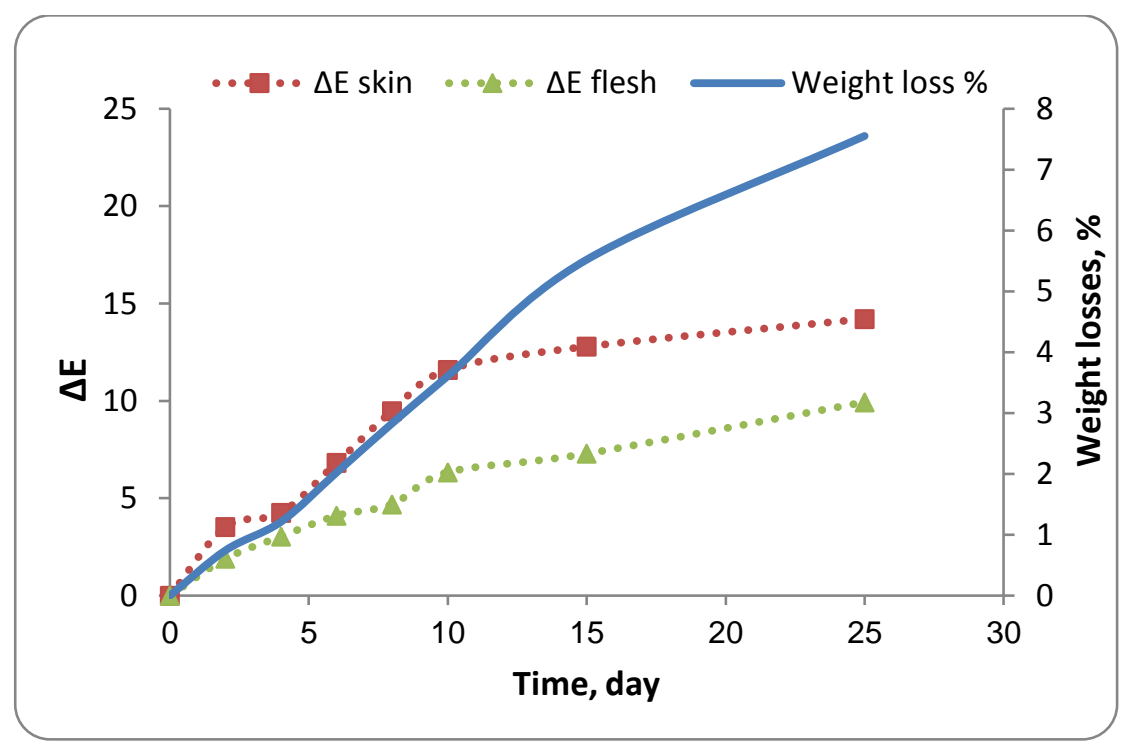

Figure 13: Effect of cold storage shelf life on total difference $(\Delta E)$ of peaches (skin and flesh) and weight losses.

The firmness decline rate was $15 \%$ after 5 days from cold storage period at $1.64 \%$ weight loss, which is less than the firmness decline rate of peaches $52.15 \%$ after 25 day from cold storage and $7.55 \%$ of water loss as shown Table (4.1). The results show that weight loss until 15 day from 
cold storage was minimal and the difference of firmness decline rate was uniform. Where peaches that are immediately stored at low temperature after harvest, observed weight loss can be up to $5 \%$ and it is considered acceptable to the consumer according to (Tareen, et al., 2012). According to moisture loss decreases the visual quality and contributes to the loss of turgor pressure and subsequent softening therefore firmness decreases with cold storage shelf life.

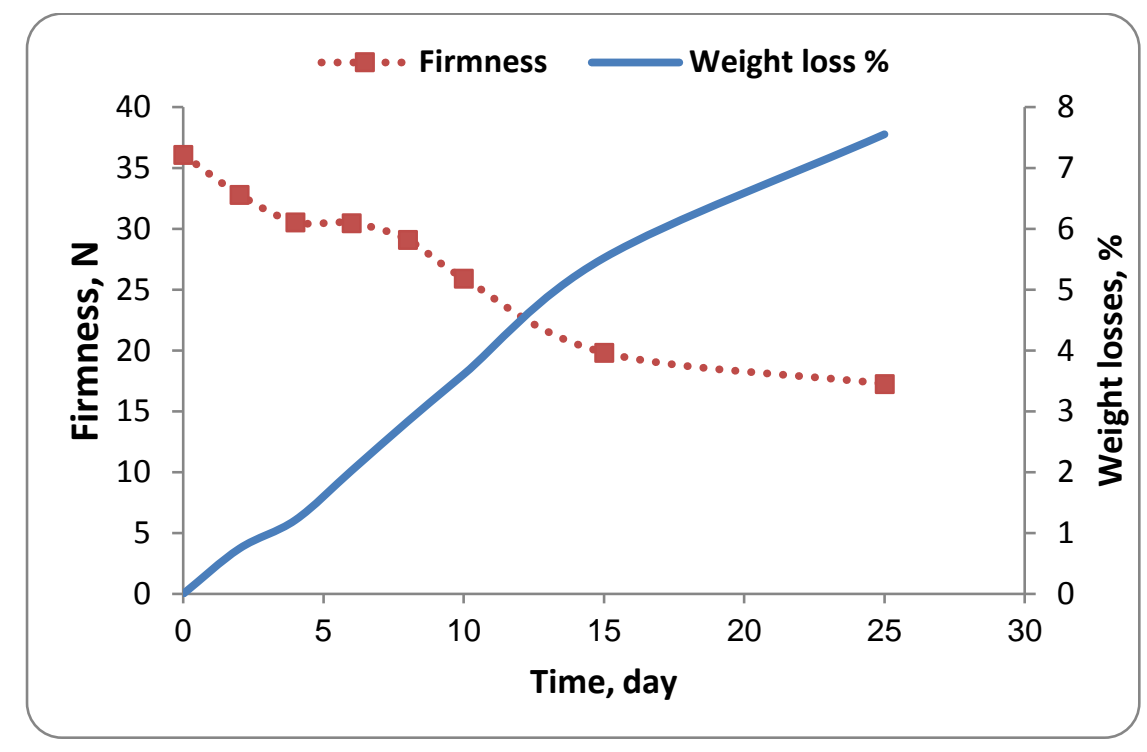

Figure 14: Effect of cold storage shelf life on Firmness of peaches (skin and flesh) and weight losses.

\section{CONCLUSION}

The experimental implementing was carried out in a cold room filled with peaches pallets. Also, experimental cold store was used to define distribution of the air velocity. The understanding of mass transfer at different situation in the cold room (upper and down position) was achieved by explanation the measured values of weight loss. The half cooling time was ranged of $1.25-1.55$ hour. After 5 days of cold storage the $\Delta \mathrm{E}$ was 2.62 and 3.47 occurred at $1.62 \%$ weight losses for flesh and skin color respectively. The weight loss until 15 day from cold storage was minimal and the difference of firmness decline rate was uniform. The 
ideal duration for cold storage of peaches from 11 to 14 day because weight losses was less than $5 \%$ and the change of color parameter in this period was not great compared to period from 15- 25 day at experimental cold storage conditions $\left(1{ }^{0} \mathrm{C}, \mathrm{RH} 95 \pm 5 \%\right)$.

\section{REFFERENCE}

Akdemir, S and E. Balb (2018) EFFECT OF TWO DIFFERENT COOLING SYSTEMS ON QUALITY OF COLD STORED PEACHES Journal of Environmental Protection and Ecology 19, No 3, 1237-1248 Clean technologies.

ASHRAE (1993). ASHRAE Handbook-Fundamentals. Atlanta: ASHRAE.

ASHRAE (2006). Methods of precooling fruits and vegetables. Chapter 22. In ASHRAE Handbook, American Society of Heating, Refrigeration and Air-Conditioning Engineers, Handbook.

Ayman H. A. E., Gomaa A. H., Abd El Maksoud M. A., El Saeidy, E. A., El Sisi, S. F (2017). Simplified Heat and Mass Transfer Modeling for Anna Apples Cold Storage. International Journal of Food Engineering and Technology. Vol. 1, No. 1, pp. 17-29.

Crisosto C H, Valero D, Layne D (2008) Harvesting and postharvest handling of peaches for the fresh market. Peach Botany Production and Uses 49: 575-596.

Crisosto CH, Mitchell FG, Johnson S (1995) Factors in fresh market stone fruit quality. Postharvest News and Information 6: 17N-21N.

Bryan, R. B., M. Anil and A. F. Brian (2011). Bulk Refrigeration of Fruits and Vegetables Part I: Theoretical Considerations of Heat and Mass Transfer, HVAC\&R Research, 2(2): 122-134

El Sisi, S. F., Ayman H. A. E., Gomaa A. H., Abd El Maksoud M. A., El Saeidy, E. A (2017) ENGINEERING STUDIES ON STORAGE OF SOME AGRICULTURAL PRODUCTS. PhD 
PROCESS ENGINEERING

Thesis, Agricultural Engineering department, Menoufia University, Egypt.

FAO (2016). Food and Agriculture Organization of the United Nations Internet site. Agricultural statistics. Www.fao.org

Gwanpua, S. G., B. E. Verlinden., M. L. A. T. M. Hertog., I. Bulens., B. Van de Poel., J. Van Impe., B. M. Nicolaï and A. H. Geeraerd (2012). Kinetic modeling of firmness breakdown in 'Braeburn' apples stored under different controlled atmosphere conditions. Postharvest Biol. Technol. 67, 68-74.

Incropera, F. P., and D. P. DeWitt (1990). Fundamentals of Heat and Mass Transfer. New York: John Wiley and Sons.

Kader, A. A (2002). Quality parameters of fresh-cut fruit and vegetable products. In: Lamikanra, O. (ed.), Fresh-cut Fruit and Vegetables: Science, Technology and Market. CRC Press, Boca Raton, USA. pp. 11-20.

Kader. A. A (1999). Fruit maturity, ripening, and quality relationships. Acta Hort. 485:203-207.

Laguerre, O., S. Duret., H. M. Hoang., L. Guillier and D. Flick (2015). Simplified heat transfer modeling in a cold room filled with food products. Journal of Food Engineering 149: 78-86.

Lurie, S., B. Shapiro and S. Ben-Yehoshua (1986). Effects of water stress and degree of ripeness on rate of senescence of harvested bell pepper fruit. J. Am. SOC. Hort. Sci. I 1 1: 880-885.

Melikov, A. K., Z. Popiolek., M. C. G. Silva., I. Care and T. Sefker (2007). Accuracy limitations for low-velocity measurements and draft assessment in rooms. HVAC Res. 13: 971-986.

Mirade, P. S and J. D. Daudin (2006). Computational fluid dynamics prediction and validation of gas circulation in a cheese ripening room. Int. Dairy J. 16: 920-930. 
Mozaffarian D, Hao T, Rimm EB, Willett WC, Hu FB (2011). Changes in diet and lifestyle and long-term weight gain in women and men. N Engl J Med.;364: 2392-2404.

Nahor, H. B., M. L. Hoang., P. Verboven., M. Baelmans and B. M. Nicola (2005). CFD model of the airflow, heat and mass transfer in cool stores. International Journal of Refrigeration 28, 368-380.

Nunes M.C.D.N (2008). 'Color atlas of postharvest quality of fruits and vegetables'. Blackwell. pp. 463.

Paulina, N., W. Aneta., M. Teleszko and J. Samoticha (2016). Sensory attributes and changes of physicochemical properties during storage of smoothies prepared from selected fruit. LWT - Food Science and Technology 71: 102-109.

Ragab, M. M. (2002). Effect of spraying urea, ascorbic acid and NAA on fruiting of "Washington Navel" orange trees. M. Sc. Thesis. Fac. Agric. Minia. Univ. Egypt. Pathol. 141: 417- 426.

Taha, A. T (2003). Simulation Model of Energy Fluxes in Passive Solar Greenhouses with a Concrete North-Wall. Ph.D. Thesis, University of Hannover, Germany.

Tareen, M.J.; Abbasi, N.A.; Hafiz, I.A (2012) Postharvest application of salicylic acid enhanced antioxidant enzyme activity and maintained quality of peach cv. 'Flordaking' fruit during storage. Sci. Hortic., 142, 221-228.

Valero, D., Serrano, M. (2010). Postharvest Biology and Technology for Preserving Fruit Quality. Boca Raton: CRC press- Taylor and francis.

Veraverbeke, E. A., P. Verboven., P. Van Oostveldt and B. M. Nicola (2003). Prediction of moisture loss across the cuticle of apple (Malus sylvestris subsp. mitis (Wallr.)) during storage Part 1. Model development and determination of diffusion coefficients Postharvest Biology and Technology 30: 75-88. 
PROCESS ENGINEERING

Villanueva, A. R., V. C. SAUCEdo, F. S. CHAVEZ, A. J. RODRIGUEZ, N. G. MENA(2000). Cold Storage of Florda gold Peach. Hort Abst, 70, 13.

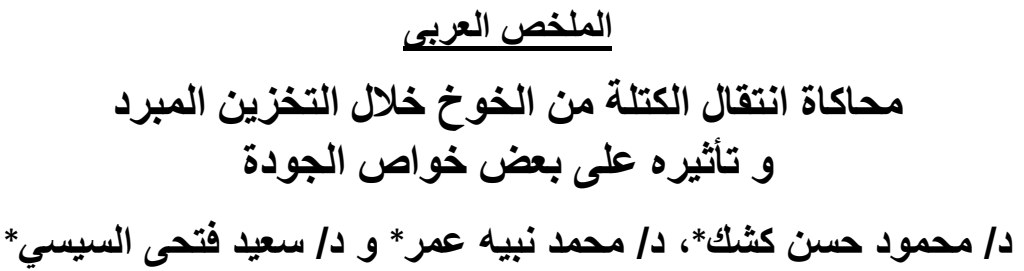

معظم المنتجات البستانية سواء الفاكهة او الخضروات تتعرض أثناء عمليات التخزين المبرد

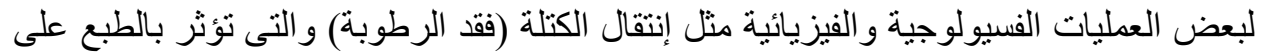

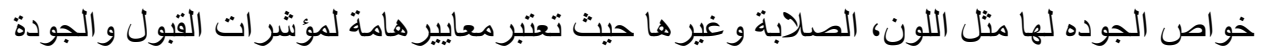
من قبل المستهلك.

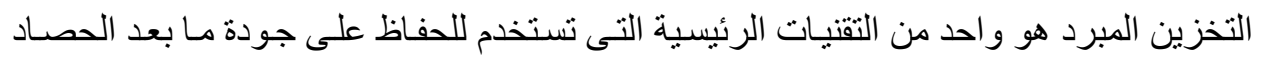

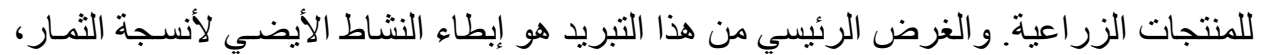

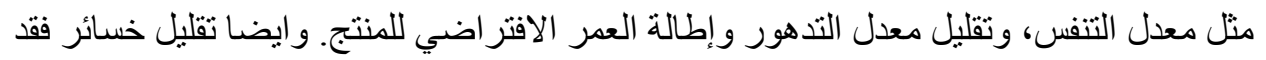

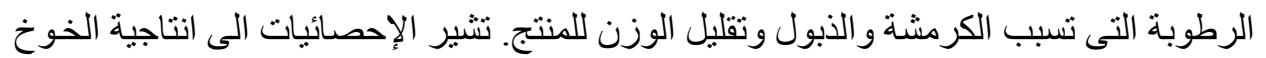

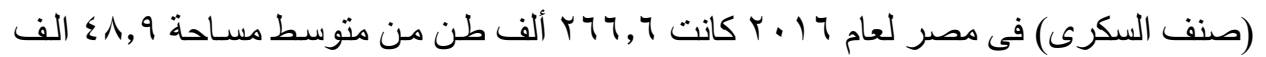

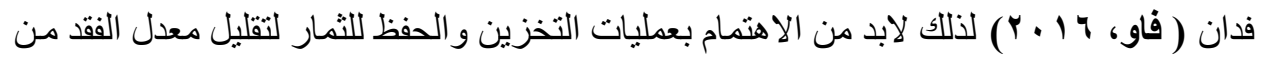

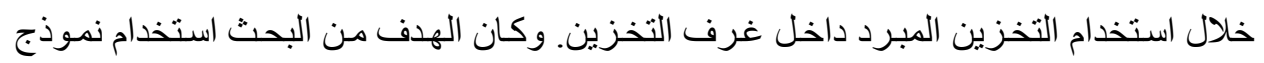

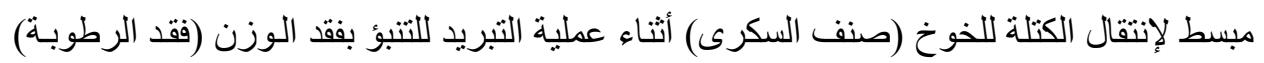

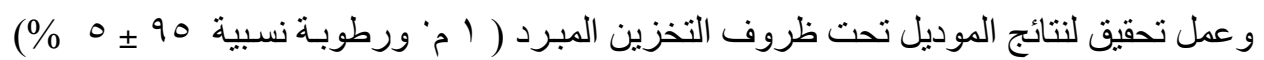

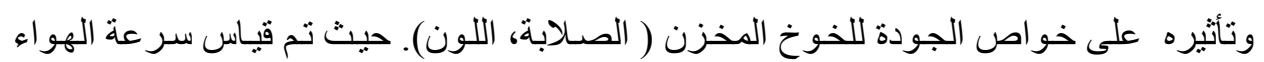

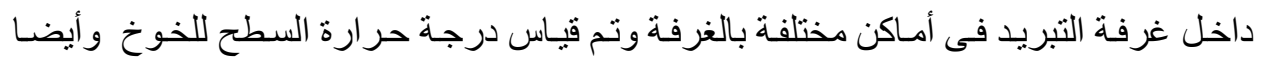

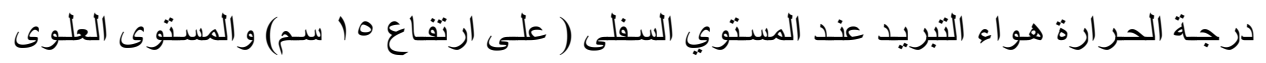

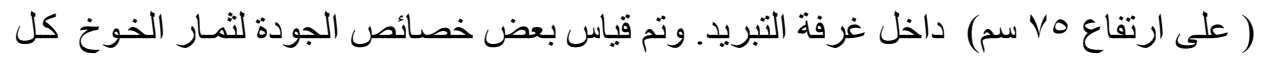

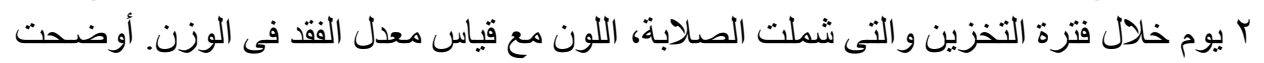

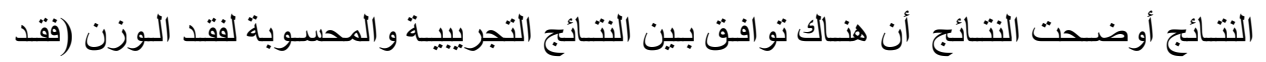

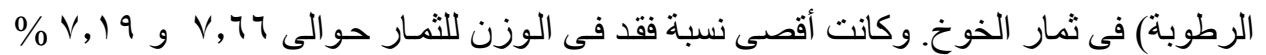

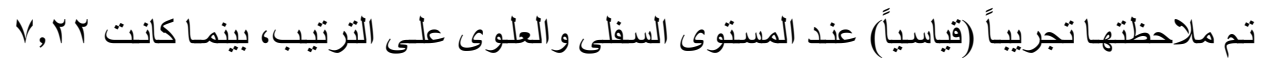

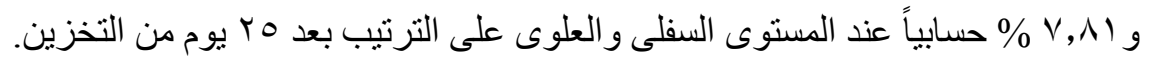

* قسم الهندسة الزراعية ـ كلية الزراعة - جامعة المنوفية - مصر. 


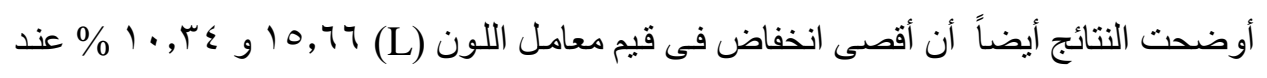

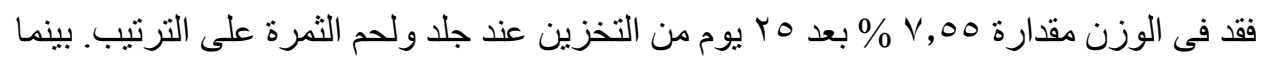

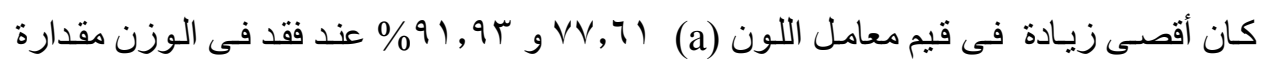

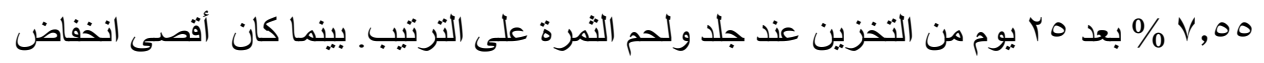

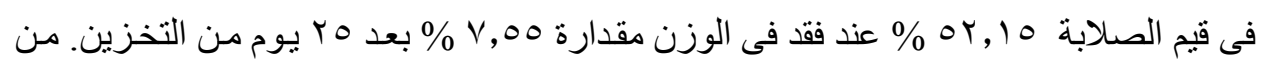

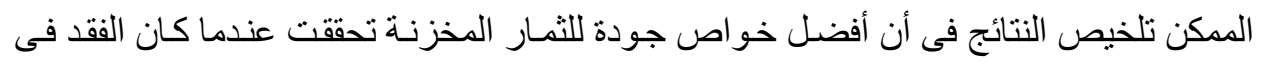

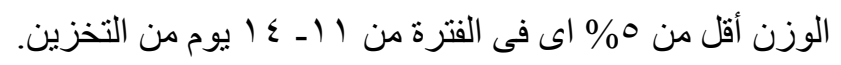

